\title{
Urban development project goals and the role of professional ignorance: ambiguous policy objectives and their consequences
}

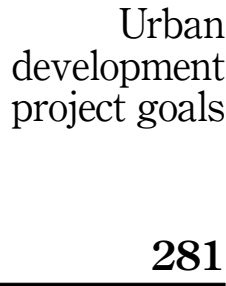

Received 17 June 2020 Revised 21 December 2020 Accepted 4 January 2021

\begin{abstract}
Purpose - Drawing on the literature on professional ignorance, here defined in affirmative terms as the capacity to act regardless of the incompleteness of available information in organizations and professional communities, the article reports empirical material from an urban development project wherein policy makers' instructions are vague and, in certain domains, inconsistent with market conditions.

Design/methodology/approach - Urban development projects regularly include uncertainty and risk taking, and policy makers' stated objectives regarding project goals may be incomplete or merely signal a political ambition. In such situations, first-line project participants need to make decisions as if uncertainties regarding policy objectives are manageable and preferably minimal. The purpose of the article is to substantiate the proposition that professional ignorance is a key mechanism in incomplete or imperfect governance systems.

Findings - Project participants actively questioned policy but acted on the instructions just the same, which is indicative of how professional ignorance is supportive of governance system that relies on first-line market actors and agencies to implement also incomplete or vaguely stated policy objectives. Incomplete policies derive from challenges in political deliberation and bargaining processes, uncertainty regarding the future and shifting preferences among policy makers and constituencies more widely. In practice, incomplete policies regularly include issues for first-level actors (e.g. on the urban development project level) to handle and to reconcile in their day-to-day work.

Originality/value - On basis of an empirical study of a major urban development project, the study contributes to a growing literature that recognizes the value of professional ignorance in governance systems and in project management practice. The study invites further scholarly research that takes an affirmative of professional ignorance but without overlooking its risks and potential malfunctions.
\end{abstract}

Keywords Urban development projects, Ignorance, Professional ignorance, Policy making

Paper type Research paper

\section{Introduction}

Project management models are essentially structured on basis of rationalist principles and mechanisms wherein costs and benefits are weighted against one another to optimize the return-on-equity investment (Lenfle and Söderlund, 2019; Hodgson, 2004). In many cases, project management devices such as time charts (Yakura, 2002) and calculative practices (Miller, 2001) serve to conceal uncertainties and ambiguities that complex projects of necessity include to generate a sense of ontological certainty and being conducive of accountability. In a milieu where the future is uncertain and cannot be anticipated in detail,

(C) Alexander Styhre and Sara Brorström. Published by Emerald Publishing Limited. This article is published under the Creative Commons Attribution (CC BY 4.0) licence. Anyone may reproduce, distribute, translate and create derivative works of this article (for both commercial and non-commercial purposes), subject to full attribution to the original publication and authors. The full terms of this licence may be seen at http://creativecommons.org/licences/by/4.0/legalcode

Funding: This study was funded by Center för Management i Byggsektorn (CMB), Sweden.

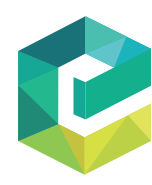

Qualitative Research in Organizations and Management: An International Journal Vol. 16 No. 2, 2021 pp. $281-298$

Emerald Publishing Limited $1746-5648$ DOI 10.1108/QROM-06-2020-1961 
QROM

16,2

rational devices serve to stabilize and render a cognitively complex situation meaningful and manageable. In urban development projects, which combine construction work activities and political objectives, say, regarding increased housing quality for low-income households (see, e.g. Van Bortel et al., 2019; Metcalf, 2018), or more vague goals such as the ambitions to reduce ethnic segregation (e.g. Faber, 2020; Diamond and McQuade, 2019; Fennell, 2017) or increase welfare more generally (Ansell, 2014; Schwartz and Seabrooke, 2008), project management practices and output are even more complicated to assess as there may be a shortage of standardized metrics regarding stipulated outcomes. For instance, how is ethnic segregation measured as a factual condition, and what are tolerable levels of ethnic segregation in a liberal and democratic society wherein individuals and families are given the decision-making authority to freely choose where to settle? Furthermore, in certain areas, as in the case of consumer credit rating (Lauer, 2017; Kear, 2017; Polillo, 2011; Poon, 2007), wherein the creditworthiness of a presumptive loan borrower is assessed, the metrics used derive from an algorithm which legally speaking is a firm-specific asset and consequently protected from outsiders' examination (Kroll et al., 2017; Citron and Pasquale, 2014). In such situations, neither the money-lender (say, a mortgage loan originator) nor the borrower (e.g. a household buying a residential home) has a detailed understanding of how creditworthiness is calculated, and yet both act on basis of such numerical information. In such situations, what is referred to as professional ignorance (Abbott, 2010), the ability to actively overlook what is in fact not known to be able to proceed, is a professional skill that guides the actor's work (Jeon, 2020; Schwarzkopf, 2020; Schaefer, 2019; Bakken and Wiik, 2018; Davies and McGoey, 2012).

This article reports an empirical study of an urban development project wherein housing renovation activities, the transformation of rental units into privately owned units and new housing production was combined with a variety of activities that were intended to increase the status and to improve the amenities of a "blighted" city district (see, e.g. Weber, 2010, p. 258). All project participants, including municipality real estate companies, private real estate developers and construction companies and city government agencies, agreed that it was important to make a concerted and coordinated effort to rehabilitate the city district as a livable and attractive residential area. One of the key objectives in the project was to get the city district off the police authority's official list over "particularly socially vulnerable city districts," an objective that was enacted by the city government and written into formal decision documents such as the project budget. Unfortunately, similar to the case of credit rating practices, police authority's measures and assessment regarding the degree of socially vulnerable city district was not disclosed, which means that project team participants acted on basis of information that was not known in detail. Consequently, project team participants were assigned the role to be held responsible for objectives whose underlying mechanisms and causes cannot be rationally assumed to be known or understood by the actors held accountable as these mechanisms were concealed to audiences. In addition, the urban development project also intended to create privately owned units in so-called community housing organizations out of the current stock of rental housing units, now owned by a major municipality-owned real estate company. In the case of this stipulated project objective, policy instructions were issued without any detailed discussions about the costs or benefits, or the wider implications of the policy if being implemented. This left project participants with two policy goals that were insufficiently detailed, but nonetheless demanded actions to be taken.

The key learning from the empirical case reported is that political objectives are frequently formulated in a vocabulary that is either vague or ambiguous (Fotaki, 2010; Romano, 2005), or that leave practical issues as a secondary concern for frontline practitioners and administrators to sort out and to determine "on the ground" (Riles, 2011, p. 232). This political decision-making process is not of necessity faulty as policy makers 
oftentimes lack a detailed understanding of practical conditions and concerns, but it may unintendedly result in a loss of accountability as, e.g. project participants in the current case can make reference to imprecise performance objectives and/or the absence of meaningful benchmarks ex post facto. Furthermore, political decision making on basis of ambiguous goals is at risk to result in so-called policy drift (Funk and Hirschman, 2014, p. 672) as project managers are given the authority to interpret political goals as it either suits their own (rather than the constituencies') interests (see, e.g. Westphal and Zajac, 2001) or in terms of what is deemed possible to practically accomplish under current conditions (i.e. project ambitions may be lowered in ways that are inconsistent with policy makers' expectations and/or instructions). Nevertheless, in the specific case, ignorance (here defined in theoretical terms, and not as a pejorative term in the conventional semantic meaning of the word, denoting the individual or collective failure to cognitively process and pay attention to available data and information) on part of both policy makers and project participants plays a key and oftentimes underappreciated role in large-scale and politically shaped urban development projects. In the end, the study contributes to the management studies, urban studies and project management literatures by demonstrating how ambiguously or poorly operationalized goals do not leave large-scale urban development projects in a state of paralysis as project team participants use professional ignorance to construct an action plan regardless of suboptimal policy instructions. Finally, the study proposes that policy making should preferably balance quite precise goals, if possible accompanied by accurate and standardized performance metrics, and social-economic broader ambitions, potentially not always easy to measure with great precision, and still render the question of accountability ex post a primary concern in policy making and governance activities.

The remainder of the paper is structured accordingly: The first section examines the concept of professional ignorance and how it is part of policy implementation in professional domains of jurisdiction. The second section accounts for the methodology of the study of a large-scale urban development project. The next section presents the empirical material. The final part of the paper discusses the results and their significance for theory developments in the field of policy studies, project management practices and domains of professional work.

\section{The social production of professional ignorance: acting under uncertainty and ambiguities}

Governance systems are oftentimes separated into principals and agents (in the agency theory vocabulary, see, e.g. Shapiro, 2005), wherein the principals are, e.g. the owners of stock in a public corporation, or politically assigned agents who are granted the authority to enact and issue policies that agents are expected to implement or otherwise recognize when making decisions. In many cases, policy making is made in abstract and vague terms, oftentimes being the outcome from political deliberation and bargaining as a variety of concerns and interests considered (Battaglini and Patacchini, 2019; Funk and Hirschman, 2014), yet intended to instruct first-level agents on how to proceed in their field of expertise. In such contexts, professional ignorance is a trained skill to selectively pay attention information and instructions that are operable within a current horizon of meaning, and on basis of stipulated budgets and project time frames [1]. Ignorance is associated with negative connotations in everyday semantics and denotes the failure to properly recognize, e.g. available information or other conditions of relevance for the situation (McGoey, 2012; Westphal and Bednar, 2005). At the same time, ignorance is a matter of fact in human lives as cognitive limitations make ignorance more of a necessity than a vice. "[P]ervasive ignorance is an intrinsic and irredeemable aspect of all individual and collective decision-making processes," Davies and McGoey (2012, p. 67) propose. McGoey (2012, p. 3) argues that ignorance is such a widespread phenomenon that it has essentially been overlooked in scholarly research: "[A]ttention to ignorance has been viewed as too obvious or banal to warrant much scrutiny"; "as an development project goals

283 
QROM

16,2

organizational phenomenon in its own right, ignorance is rarely problematized," Schwarzkopf (2020, p. 198) adds.

In the management studies literature, there is a renewed recognition of ignorance as a form of trained skill (Schaefer, 2019; Souleles, 2019). Jeon (2020, p. 842) refers to the "social production of ignorance," which is "orchestrated by the power inequalities at the structural level." For instance, the concept of strategic ignorance denotes how, e.g. institutions and organizations are capable of "deploying societal ignorance for the service of their own interest" (Jeon, 2020, p. 842). On the more practical level, on the level of the interaction order (Goffman, 1983), individuals "construct, justify and secure a common perception of their world via interactions" (Jeon, 2020, p. 843) so that certain conditions are downplayed or overlooked, while other are foregrounded. Consequently, the social production of ignorance on the group level should be seen as "a relational product of collaborative efforts," in turn being "embedded within various positions at the organizational field, with taken-for-granted routine and habitual mode of thoughts and practices" (Jeon, 2020, p. 844). To provide two practical examples, McGoey (2012) suggests that judges who make legal decisions in the court of law actively ignore emotional conditions in their pursuit for justice based on factual evidence. In scientific practices, to ignore certain ambiguities to enhance the "generalizability of scientific findings and to attain consensus about the merits of a new discovery" is conducive of the individual scholars' reputation for "scientific sobriety" (McGoey, 2012, p. 4). In the case of scientists' professional ignorance, "scientists value ignorance as much as the knowledge they produce - it is a means of survival and professional development," Jeon (2020, p. 857) writes.

Also in day-to-day occupational work, professional ignorance serves a variety of interests and maintains the day-to-day business operations. For instance, Fine's (1996, p. 36) ethnography of restaurant chefs somewhat surprisingly reveals that individual cases of food poisoning - understandably a disastrous event for a restaurant if it is deemed culpable for the event - are ignored by "cooks, inspectors and journalists" as such events are regarded as being part of the business and dining out and can rarely be traced in any meaningful way. The credo that "The show must go on," shared by a variety of market actors, may abhor food poisoning victims and sensitive audiences, but this ignorance arguably enables the operations to continue at the same time as a number of actors recognize the need to learn from these unfortunate but ultimately understated cases. Importantly, in this context, "being ignorant" does not denote a situation wherein the agent has incomplete knowledge or lack knowledge altogether, but rather ignorance denotes "deliberate inattention" (Schaefer, 2019, p. 1,389). For instance, when intendedly being inattentive to details, an agent can protect him or herself against accusations of culpability ex post facto, Souleles (2019) argues, which indicates that professional ignorance is a learned skill in its own right. This skill is of particular value in situation wherein agents operates in a milieu characterized by overwhelming complexity (as in the case of finance trade; Souleles, 2019), or wherein either objectives or the means to achieve declared objectives are obscure or concealed to the actor. This latter situation will be examined in more detail below.

\section{Incomplete or concealed performance metrics}

In the United States, wherein the access to credit markets is part of a full economic citizenship and conducive of economic welfare (Lauer, 2017; Polillo, 2011), the so-called FICO score is the credit market industry standard measure of a presumptive borrower's creditworthiness. In the American consumer lending market, the "big three" consumer rating agencies of Experian, Equifax and TransUnion accounts for over $90 \%$ of the market (Rona-Tas and Hiss, 2010, p. 118), and currently, FICO scores are used "in ninety percent of lending decisions in the United States” (Fourcade and Healy, 2013, p. 561). The acronym FICO denotes Fair and Isaac 
Co., a privately owned corporation that uses an algorithm to calculate a credit score on basis of a number of parameters (Poon, 2007), but whose details are not disclosed to market actors neither lenders nor borrowers. By design, the FICO measure calculates the "probability of a negative credit event over a two-year horizon" (Keys et al., 2009, p. 316), which means that, e.g. mortgage lenders, who frequently originate loans with a thirty-years maturation period (as in the case of mortgage lending), can only assess the short-term solidity of the client. Furthermore, it is known that the FICO score includes parameters such as (1) payment history, (2) amounts owed, (3) length of credit history, (4) new credit and (5) types of credit used (Karger, 2005, pp. 46-47), but otherwise the three-digit credit score being issued remains "a process that cannot be fully understood, challenged, or audited by the individuals scored or even by the regulators charged with protecting them" (Citron and Pasquale, 2014, p. 10). Credit bureaus "routinely deny requests for details on their scoring systems," and consequently "no one outside the scoring entity can conduct an audit of the underlying predictive algorithms," Citron and Pasquale (2014, p. 10) write. Presumptive borrowers therefore act in the dark regarding how to "work the credit score" (Kear, 2017, p. 358) as the scoring systems that provide the access to credit markets "are shrouded in secrecy ... [and] the algorithms are zealously guarded trade secrets" (Citron and Pasquale, 2014, p. 5). While this secrecy protects the consumer credit rating agencies from critical scrutiny, the inability to demonstrate how what Kiviat (2019) refers to as "actuarial fairness" - fairness in terms of each individual being assessed individually and not as a representative of a larger socioeconomic or even ethnic group - is ensured, result in a legitimacy problem for credit rating agencies. This legitimacy problem is derived from the inability to rule out that the calculated FICO scores are not biased in any measure.

In analogy with the FICO score and the consumer credit rating business, in the urban development project being reported in the empirical section, the police authority's rating of the degree of socially vulnerable city districts, presented to audiences as a taxonomy including three levels of perceived social vulnerability (but with no internal ranking within categories) are based on police authority metrics and field work reporting, yet concealed to other authorities and agencies and to the wider public. Despite the opaqueness of the taxonomy - which largely runs counter to the overall reverence of transparency in all corners of the governance system (Mehrpouya and Salles-Djelic, 2019; Pozen, 2018; Kosack and Fung, 2014) - policy makers in the local city government was anxious to reduce the number of city district in the highest taxonomy class (being labeled as "particularly socially vulnerable city districts"). Consequently, one of the primary performance metrics in the urban development project was to ensure investments and other activities that would increase the socio-economic welfare of residents so that that the targeted city district would be excluded from this category. As indicated by the empirical material, the reference to the police authority's taxonomy resulted in much deliberation in the project team regarding how to achieve a stipulated and politically defined goal, whose empirical substantiation is concealed to audiences, including the project workers themselves. However, professional and trained ignorance in the form of "deliberate inattention" was needed to operate on basis of political objectives while at the same time accomplishing project goals that potentially would result in the stipulated goals. In the end, the empirical case demonstrates how ignorance is a vital skill when operating in milieus shaped by political objectives that only insufficiently take into account practical conditions, and what are in facts doable within stipulated project budgets and time frames.

\section{Methodology}

Design of the study

The study reported in this article is based on a case study methodology (Gillham, 2000; Stake, 1996). Gerring (2004, p. 342. Original emphasis omitted) defines a case study as "[a]n intensive

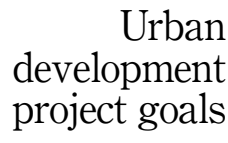

285 
QROM

16,2

study of a single unit for the purpose of understanding a larger class of (similar) units. A unit connotes a spatially bounded phenomenon ... observed at a single point in time or over some delimited period of time." The conventional wisdom regarding interpretative methodologies, such as case studies, is that the scholar must present a "faithful and authentic representation of people's perceptions of their lived experience" (Eisenhardt et al., 2016, p. 114). More specifically, urbanism studies and studies of urban development oftentimes use cases study methodologies, both in the case of classic studies such as William F. Whyte's ((1943) 1993)

Street corner society, and more recent studies of urban renewal in city districts in, e.g. London (Beswick and Penny, 2018), Berlin, New York (Fields and Uffer, 2016) and Paris (Guironnet et al., 2016).

The case being studied is a cross-organizational urban renewal project in a northeast inner suburbs in a Swedish metropolitan area, and the project included municipality real estate companies, private real estate developers and city administration representatives. Sweden is widely regarded as a welfare state with a high proportion of the GDP being taxes serving to redistribute economic wealth, but since the turn of the millennium, Sweden has doubled the proportion (from 10 to $20 \%$ ) of the population born outside the country due to migration and a generous asylum seeker policy. Since the 1950s, Sweden have received migrants and guest-workers, originally from Southern Europe and neighboring Finland primarily, but in the 1990s and after year 2000, the proportion of non-European immigrants have increased markedly. According to Swedish migration law, enacted in 1994 but subject to modification in 2020 due to perceived difficulties to uphold the legislators' intention on the municipality level, newly arrived migrants have the right to choose where to live as long as they can find housing, and one of the consequences of the policy was a concentration of immigrant groups in suburban areas in the largest cities. Many of these suburban areas were constructed in the 1965-1975 period, wherein the government launched the ambitious "one million housing units" program, widely debated ever since but largely being an adequate response to inner city population density problems, population growth and urbanization more widely. So-called million units city districts have been in operation on basis of the original design and organization for over more than five decades, but recent upsurge in, e.g. street crime including drug dealing and shootings and violence in criminal communities, widely covered in news media reporting and in political debates, there is a perceived need for turning the tendency toward "ghettofication" on basis of urban renewal initiatives. The current project was initiated and managed by a major municipality real estate company, owning no less than $94 \%$ of the housing units in the targeted city district. The city district is characterized by medium to low net-worth households (with a majority in the lower end) including circa 9,000 residents in total, high degree of unemployment in comparison to the national average (circa 12\%), a high proportion of immigrants, including 97 different nationalities being represented among the residents and a "blighted" suburban milieu. As the municipality real estate company make significant investment in cleaning services to keep the public spaces and the housing facilities in a good condition, the first impression of the city district when visiting is far from alarming, but the socio-economic welfare of residents are lower than the city average on a variety of official measures. Furthermore, the Swedish police issues reports that name city districts that are "socially vulnerable" or "particularly socially vulnerable" - district characterized by high degrees of street crime and other social and economic risks. The city district being studied is one out of six such especially socially vulnerable districts in the local metropolitan area.

The specific case is of relevance within professionalism studies framework as it underlines how project goals on the one hand need to be wide-ranging and ambitious, while on the other hand, they need to be precise enough to inform and direct project decisions. 


\section{Data collection}

The data collection included three sources of data. First, interviews were conducted with representatives of the companies and organizations participating in the urban renewal project. Interviews were conducted in situ, in most cases in the offices of the interviewees. The interviews were structured on basis of an interview guide, were recorded and lasted for a median duration time of approximately $1.5 \mathrm{~h}$. All interviewees were asked basically the same questions, but the interviewers left much space for individual reflections and asked follow-up questions of relevance for the wider project whenever the opportunity emerged. The interviewees were asked what they thought were the key objectives with the current project, if they thought the project budget was sufficient to accomplish such stated goals, and how they perceived their own role in the project. Interviewees were also asked to more generally reflect on regional and national urban development policies and their historical track records in terms of providing affordable and qualitative housing for, e.g. low net-worth households. Some interviewees, including project leaders and the CEO of one of the municipality real estate companies, were granted more formal authority and were consequently asked more detailed questions regarding project objectives and design. In the first phase of the project, 20 persons were interviewed, and the sample included the project leader and the project management team, business development directors in private and municipality real estate companies, CEOs of municipality real estate companies and other expert groups participating. Second, the research team participated during project meetings wherein either the contractual conditions or agreements pertaining to project activities were determined, or where specific project activities were discussed. During such participative observations, field notes were written to account for the issues being addressed and topics being debated in the project team. Table 1 summarizes the data acquired on basis of the first two data collection methods.

Third and finally, internal documents and reports issues by the participant organizations were retrieved and used as input material for understanding how large-scale urban renewal project are managed and handle a variety of interrelated project goals.

\section{Data analysis}

As indicated above, a major concern regarding the use of case studies is whether the research method is inductive, i.e. starts with empirical observations and only thereafter introduces theoretical perspectives to explain or make sense out of the empirical data, or an abductive method, wherein original theoretical propositions are recognized as the means for making interesting empirical observations. Regardless of what position taken in this debate, the empirical data, e.g. interview transcripts need to be coded according to a standardized procedure. Gioia et al. (2013, p. 20) distinguish between first- and second-order coding, wherein first-order coding (which Strauss and Corbin, 1998, refer to as "open coding") quite broadly introduce empirical categories to label or describe interview excerpts. In the secondorder coding procedure ("axial coding" in Strauss and Corbin, 1998), theoretical codes that are broader and more inclusive than the first-order codes are introduced to reduce the number of codes to "a more manageable number" (Gioia et al., 2013, p. 20). Based on these second-order
Urban
development
project goals

287
Data collection method

Interviews

Project meetings participation

Informal conversation with project team members

In total
Total time

$23 \mathrm{~h}$

$5.5 \mathrm{~h}$

$3.5 \mathrm{~h}$

$32 \mathrm{~h}$
Table 1.

Data collected in the research project 
QROM

16,2

codes, the theorizing process is intended to formulate new theoretical categories, ultimately connected in a logically consistent and plausible manner, consistent with the empirical data and fitting with other theoretical concepts.

The interviews were transcribed verbatim by a professional writing bureau, and the firstorder coding included nine categories that basically labeled the various themes discussed during the interviews. Such first-order codes included quite broad labels such as "Project work practices and intended outcomes" (including issues related to the specific project work and project organization), "The qualities and social status of the city district" (discussing local city district challenges and opportunities) and "Swedish rental units contract policies" (addressing how housing unit rents are determined in the Swedish municipality housing model). These nine first-order categories were structured into three second-order categories, labeled as (1) "The specific urban development project" (which included four of the nine firstorder coded interview excerpts), (2) "Swedish urban development policy" (which included two first-order coded interview excerpts, and addressed the regional and national urban policy more generally, being of relevance for the focal project but otherwise being the outcome form nested institutional, legal and political conditions) and (3) "The housing market" (which included three first-order coded interview excerpts, and more generally addressed the commercial and financial conditions in the Swedish housing market). In the empirical section presented below, the first subsection ("How to achieve political goals when the data is concealed to decision makers") roughly includes interview excepts from the first second-order coding category, whereas the second subsection ("The increase of community housing supply in the low-end of the housing market") addresses issues related to the second and the third second-order coding categories ("Swedish urban development policy" and "The housing market"). Through this coding procedure, the empirical material is structured into analytical categories that are related to the overarching theoretical proposition, namely how professional ignorance may play a role in urban development projects whose objectives and means to accomplish such objectives are understated at the same time as social, economic and political realities still demand qualified professional action. Furthermore, by conducting this coding procedure strictly and following the credo that the research should make a "faithful and authentic" account of the empirical data, the empirical material reported below serves the two ends to demonstrate how project objectives were approached and the theoretical significance of such activities and decisions.

\section{Professional ignorance in urban development projects}

In the Swedish housing markets, municipality real estate companies play an active role in the mixed economy governance framework in providing affordable housing for low net-worth households and by acting as a market marker. The municipality real estate company is an incorporated business, in most cases fully owned by the municipality and thus subject to political directives and goals, yet intended to operate on basis of sound business principles so that private companies can compete in the housing market. Municipality real estate companies are oftentimes a major landlord in the larger cities' suburban districts that primarily hosts medium to low net-worth households, but the housing stock may also include units in inner city districts and in more lucrative locations. Being active in providing qualitative affordable housing for less affluent tenants, while maintaining a functional housing market, municipality real estate companies are subject to political decision making and policy. To fulfill political goals while reducing market disturbances to a minimum and under conventional business principles are complex assignments that demand clear governance rules that restrict direct political influence. In the following, two cases of political objectives shaping an urban development program will be examined. First, an urban development project was initiated with the explicit political objective to eliminate the targeted city district from the police authority's national list over "particularly socially vulnerable" 
city districts. Second, in order to create possibilities for a "housing career" among the residents, policy makers wanted to support an increase in "mixed housing," as recommended by the United Nation's committee for affordable housing. This second goal demanded that rental units were transformed into privately owned so-called community housing units, wherein each apartment is owned by the resident while the resident pays a monthly fee to the community housing board of directors (recruited from the residents in the building), which is held responsible for the maintenance and the running costs of the housing unit. To own one's apartment is commonly portrayed as an upward movement in the "housing market career," which in turn is associated with positive socio-economic consequences. Both these objectives were politically justifiable on basis of the current governance model, yet the details and the practical implications derived from such political objectives were understated. Consequently, to be able to act on basis of vague and/or incomplete policy decisions, professional ignorance served to eliminate a proportion of issues and questions that would block joint action for a considerable period of time. Similar to the scientists who ignore what they do in fact not know for the time being, to be able to extract meaningful information from the data generated in an experimental system, the project team professionally ignored that they did not had a complete understanding of the conditions influencing their work, but nonetheless they initiated and participated in the urban development program. In the following, conditions included in the policy, yet being poorly mapped and known in substantive terms, but consequently guiding project decisions are examined on basis of the empirical material.

\section{How to achieve political goals when the data is concealed to decision makers}

The CEO of the municipality real estate company that owned no less than $94 \%$ of the rental units in the city district argued that her organization was in the position to simultaneously handle "a complex political process" and "a physical reality" (i.e. the day-to-day housing activities in the capacity of the landlord). That is, on the one hand, policy makers regarded the municipality real estate company as a tool for the realization of policy objectives, ranging from abstract visions to concrete goals; on the other hand, the municipality real estate company handled a great variety of "on the ground" activities, of great importance for the welfare and quality of life of the tenants, by and large separated from political deliberations. When policy makers express their ambition to create a more mixed housing market in the city district, the municipality real estate company needs to balance such political objectives, embedded in international guidelines and instituted by academic research work, against how this will affect the welfare of current and future residents. For instance, if new privately owned housing units are constructed in the city district, will this generate a net welfare effects for all residents (as stipulated by the theory of positive externalities that guide international policy recommendations; see, e.g. Chetty et al., 2016), or does it further stratify the residents into discrete groups? For the private companies being involved in the urban development project, it is not so much political objectives as the actual purchasing power of presumptive home buyers that matters. "The land slots are not worthy very much for the time being," one business developer said (\#1, Private company, Male): "Today, you would not be able to build anything there [with a positive return]." At the same time, having extensive experience from the industry, the business developer understood the value of maintaining a long-term perspective:

If we are part of this, we need to take a long-term view. I'd say it takes at least ten years, possibly twenty [to turn things around]. And the City Hall needs to be part of the process. During the first five years, there may be no black bottom line figures. (Business developer \#1, Private company, Male)

The main concern regarding the valuation of new housing units and the transformation of rental units into community housing units was that visible street crime and covert criminal activity would suppress the willingness of presumptive buyers to make an investment in the 
QROM

16,2

city district. One of the principal targets for the urban development project was therefore to be eliminated from the policy authority's list of "particularly socially vulnerable" city districts. The project participants thought this was a reasonable goal at the same time as they emphasized that this list did not reveal to audiences what parameters that were included, which imposed a fair share of uncertainty regarding what actions to take to accomplish the stipulated goal. A project pre-study coordinator (\#2, Female) argued that the list included qualitative and "subjective" assessments, and therefore the project team should determine whether getting off the list was a "relevant measure to use or not?"

In addition, the police authority listing was inconsistent with other available metrics. Tenant satisfaction surveys revealed that most of the tenants were "fairly pleased," the urban development project leader said. The city district was not on top of the list of all the municipality real estate company's neighborhoods, but the survey data reveal no particularly worrying conditions. Regarding perceived safety, little indicated that tenants regarded their city district as being unsafe, despite the police authority list. In addition to the ambiguities pertaining to the policy authority assessment, and its accuracy regarding perceived safety among residents, several of the interviewees argued that the policy makers' ambition to get the city district off the list was a most difficult goal to accomplish within the stipulated shortterm time horizon. Said the project pre-study coordinator: "There's nothing right now that indicates that the political goal that there would be no particularly socially vulnerable city districts by 2025 will be met. There is nothing that even moves in that direction" (Project prestudy coordinator \#2, Female).

If policy makers fail to prescribe project goals that are clearly defined, nor achievable within stipulated time frames and budgets, there is a need for alternative performance measures to coordinate project activities. Such performance measures could be allocated "upstream" (as in the case of local schooling quality and schooling results) as being predictors of problems surfacing in the future unless being properly handled, or "downstream" (as in the case of the valuation of the housing stock and the market prices and market price differentials in newly produced housing). All project participants and informants agreed that schooling quality was of great importance for reducing the risk of inclusion in criminal activities later on, especially for boys and younger men as indicated by official data. A school agency representative was included in the project team, but unfortunately the agency had few possibilities for allocating additional resources to specific school districts on basis of urban development initiatives; the school agency operates on basis of legislation, regulatory rules and protocols that emphasize the needs of individual pupils, not to be supportive of the market pricing of housing facilities in specific city districts or any other policy objectives. At the same time, school agency representatives understood that their cooperation was a key to the policy makers' stated objective to increase the welfare in low-income city districts. Regarding the second performance metrics, representatives of the private companies who participated in the project emphasized how sales and market prices were credible indicators of project performance: "The ultimate evidence of a successful project is if newly build housing is being sold. That would indicate a market interest, and faith in the city district. Otherwise, there would be no sales," a business developer argued (Cooperative building society, Female).

Regardless of what metrics being used, all interviewees argued that some kind of measurement to monitor project performance was needed, especially given the vague instructions from policy makers. Furthermore, to actually increase the welfare of residents and to support a market for new housing and cooperative housing units, a variety of activities and initiatives had to be mutually supportive. For instance, to build new housing without paying attention to perceived safety and schooling quality concerns is unsustainable, while on the other hand, to merely focus on social issues without making actual investments is at risk to render such social initiatives merely symbolic in the eyes of residents and other audiences. In this view, to make the project team take action on basis of the policy makers' 
instruction to eliminate the city district from the list of particularly socially vulnerable urban areas demand professional ignorance in terms of overlooking the opaque nature of stated objectives, and the absence of details regarding the substance of the assessments underlying to such objectives.

Prior to examining the theoretical implications, the second case of policy makers' instructions, in this case regarding the transformation of rental units into cooperative housing units, is presented. Similar to the case regarding police authority assessments, policy makers' instructions are vague to the point where "on the ground" activities need to include a considerable degree of informed guess-work regarding how to implement the policies enacted by democratically elected entities. In other words, to proceed on basis of such instructions, professional ignorance is supportive of practical activities despite considerable ambiguities regarding assumptions made, the process to be managed and desirable outcomes.

\section{The increase of community housing supply in the low end of the housing market}

According to the United Nation's housing agency, which several of the interviewees referred to during the interviews as being the basis for the current housing policy, mixed housing is both an indication of and a pathway toward increased socio-economic welfare in a city district. If rental units are combined with the possibilities for privately owned housing, local residents and incoming residents can make a "housing career," and positive externalities is stipulated to follow from the increased degree of residents included in the labor market settling in the city district. Based on these premises, anchored in both theoretical models and empirical evidence, local policy makers argued that the proportion of rental units was too high, and that community housing units should be provided to create a more dynamic housing market in the city district. While the project leader argued that few of the residents were moving out of the city district, and that a significant proportion of the residents had "moderate" purchasing power, many of the interviewees were skeptical regarding the efficacy of the policy makers' ambition to transform rental units into community housing. By and large, there were three principal concerns regarding the projected welfare of such initiatives. First of all, the limited purchasing power and the lower degree of labor market inclusion of the residents would make it difficult for them to make the long-term commitment an investment in a community housing unit would entail. Second, as a response to the financial crisis of 2008, regulatory agencies that monitor the mortgage-lending industry have imposed stricter lending rules that makes it more difficult for medium- to low-income households (which also include young people and younger families) to access mortgage loans. As the state does not meddle with market-based mortgage lending activities or provide direct subsidies at the mortgage loan origination stage, presumptive community housing buyers are therefore likely to encounter difficulties when financing their purchase. Third and finally, the community housing ownership model demands a certain degree of expertise regarding how communal cooperative housing resources are managed and financed, e.g. how the cooperative housing unit is governed on basis of a board of directors selected from the pool of residents. Individuals who have spent most of their lives in rental units must learn that the costs and responsibilities previously being carried by the landlord are now being a responsibility of the residents themselves. A business developer in a private company, specializing in producing privately owned of community housing units, emphasized the "educational demand" and the role of private companies in instructing prospect cooperative housing residents in how to handle a series of responsibilities that the community housing corporation carries:

There is an educational demand here as few have owned their homes and have limited know-how regarding what that means. So we provide a fair share of support to newly created community housing corporations ... What is ownership of an apartment in a community housing corporation? 
QROM

16,2

292
The board of directors, the residents, how does all that work? What are individual and communal responsibilities? (Business Developer, Private real estate developer, Male)

Regardless of such support and help from both municipality real estate companies, and private companies active in the low-end housing market, many of the interviewees regarded the market for community housing units as being thin. Given these conditions (low purchasing power among the low net-worth households being the presumptive buyers, stricter mortgage-lending regulation, and an estimated shortage of know-how needed to successfully manage a cooperative housing corporation), several of the interviewees regarded the policy makers' instructions as being overoptimistic. The CFO of a municipality real estate company expressed his concern regarding the efficacy of the stated policy:

To merely declare that 'Start creating community housing units and so forth because that would lead to improvements' [is insufficient]. I don't believe in that. I think the difficulties in making [the tenants] understand how this works and what it takes are gigantic. (CFO, Municipality Real Estate Company)

Policy makers may have the full faith and confidence in market actors' ability to generate a local cooperative housing market, but the cost and effects on long-term welfare for the residents are concerns that are left in the dark in the current policy instructions. The CEO of the municipality real estate company that owned the absolute majority of the housing stock said the community housing units would be created on basis of the available rental housing stock:

In the first place, this is a matter of being able to offer new possibilities that does not make the step to buy a newly produced apartment appear as an insurmountable achievement. We believe that transforming rental units into community housing units may speed up this process more than in the case of building entirely new [community] housing units. (CEO, Municipality Real Estate Company, Female)

At the same time, the rental unit tenants' national interest organization, Hyresgästföreningen, has repeatedly emphasized that every time a cooperative housing unit is created on basis of one rental housing unit being transformed into privately owned apartments, the dynamics of the housing market may increase in theoretical terms, but it also reduces the total stock of rental units that are available for, e.g. new entrants on the housing market. In this view, the tenants' interest organization object to the privatization of the current housing stock (but, importantly, still being supportive of newly built cooperative housing) as this policy is deemed to reduce the overall welfare. In the case of the policy making preceding the specific urban development project, it was more general and consequently more abstract housing policy guidelines that was mirrored in the policy instructions. Furthermore, the center-right political majority of City Hall, established after the general election of 2018, was generally more positive toward the idea of home ownership as a welfare generating device than the social democratic political majority ruling prior to 2018 . The new policy was thus part of a more comprehensive shift in governance practice that also included municipality real estate companies.

Under all conditions, policies tend to be enacted in general terms, and thereafter delegated to defined agencies and assigned private companies and market actors to implement (Riles, 2011). Policy ideas that appear to be theoretically consistent, embedded in robust evidence and harmonized with international agreements and directives but nevertheless being enacted in abstracto may impose considerable difficulties when being interpreted and translated into proper action by "frontline" actors (see, e.g. Edelman et al., 2001; Edelman, 1992). In the specific case of the urban development project, the ambition to get the city district off the police authority's list is reasonable, but only if agents' assigned decision making is consistent with and supportive of stipulated policy goals and objectives. In the current situation, that was not unambiguously the case. In the case of the policy to increase the proportion of 
cooperative housing units in the city district, formally enacted policies were passed on and further pronounced on basis of the belief in privately owned housing being conducive of net social and economic welfare, but there were few instructions regarding how to accomplish such goals given the current housing and mortgage-lending market conditions. Neither were there any extensive deliberations or assessments made regarding the risks, unintended consequences or externalities generated in the transformation of rental units into cooperative housing facilities, neither for the local community nor more broadly on the regional or national level. Under such conditions, to be able to navigate in housing markets that are shaped by policy making, yet instituted as bone fide market activities "on the ground" (as in the case of mortgage lending), professional ignorance is a mechanism or learned skill that serve to create possibilities for meaningful practice in the shadow of perceived policy making inconsistencies and/or uncertainty regarding the future more largely.

\section{Discussion}

In order to act, humans and, as in this case, project teams need proper know-how and information to act upon. In the absence of favorable conditions in such terms, assumptions are made to "fill in the blanks" and to create a shared ground for, e.g. project activities (Weick, 1995; Daft and Weick, 1984). Being in the position to act on basis of incomplete, ambiguous or contradictory information or instructions is a regular condition in governance systems (Mehrpouya and Salles-Djelic, 2019; Kosack and Fung, 2014), and professional actors must learn to cope with this predicament (Lifshitz-Assaf, 2018; Hayward and Boeker, 1998; Gerrity et al., 1992). Professionalism is based on the capacity to act individually and collectively on basis of a combination of available information, assumptions made on basis of previous experience, extrapolations made on basis of existing data and qualified guess-work (Freidson, 2001; Abbott, 1988). In governance systems characterized by political decision making, wherein preferences, priorities and agendas change over time, and where policy makers rely on qualified professional agents to handle the practical work to implement and to materialize policy (Riles, 2011), policy instructions are frequently vague or incomplete, which oftentimes result in policy implementation being a mere afterthought - an issue for lower-tier functionaries and market actors to practically handle (see, e.g. Kellogg, 2014; Edelman et al., 2001). Under such conditions, professional ignorance is supportive of policy implementation as it both recognizes the policy makers' stated intentions, and mindfully neglect the incompleteness of the instructions.

Scholars argue that ignorance is "rarely problematized" (Schwarzkopf, 2020, p. 198) despite being an "an intrinsic and irredeemable aspect" (Davies and McGoey, 2012, p. 67) of decision-making processes. In the urban development project case reported in this article, the "strategic ignorance" (Jeon, 2020, p. 842) and the "deliberate inattention" (Schaefer, 2019, p. 1,389) of the project participants, representing a variety of market actors and agencies including both private companies and municipality real estate companies, played a key role. In the specific case, stipulated (negative) performance metrics was concealed to project co-workers, which potentially prevented informed decisions regarding how to achieve project goals, and the ambition to create a market for mixed housing was to a considerable extent based on ideological preferences than based on substance regarding actual purchasing power in the local housing market. Despite policy makers' broad-sweeping decisions and instructions regarding desirable outcomes and preferred future conditions, the project participant acted on basis of stipulated project goals, formulated on basis of policy objectives. In this context, professional ignorance denotes the capacity to create an alignment between factual conditions, available resources and declared or assumed goals, to generate an action plan that is plausible in the eyes of relevant actors. If successfully handled, such action plans generate material consequences within existing budgets and time frames, regardless of 
QROM

16,2 inconsistencies in problem definitions, the resources assigned to their solutions and projected outcomes.

Urban development projects, especially in low-end housing markets where the purchasing power of targeted buyers is modest, are in many cases surrounded by uncertainty (e.g. regarding labor market conditions that immediately affect the purchasing power of households with limited savings) and include risk-taking (e.g. in terms of assessing presumptive home buyers' access of credit). To better assess risks and uncertainties, a variety of market actors and agencies are represented in the urban development project team to collectively cover a larger number of joint concerns of practical relevance for the project. Such complex urban development projects demand communication skills and the capacity to recognize the role and interests of all participants. At the same time, different actors participating need to ensure that they can benefit in ways that are consistent with individual goals, or else the output may be meager. That is, urban development projects include a considerable amount of bargaining so that all participants are better off in the end. In the ideal case, policy makers make decisions that are supportive of such team-based and crossorganizational bargaining activities and the activities that are decided in this process, with decisions being sufficiently precise to generate an action plan for the participants, yet flexible and open to interpretation so that a variety of interests can be recognized and contained in one single instruction. In many cases, such qualified policy instructions are not provided, which put pressure on project participants to jointly formulate how activities should unfold over time, and to what end they are introduced. Professional ignorance here denotes the trained and learned capacity to overlook the fact that data and information may be missing and to circumvent incomplete instructions on basis of joint assumptions and/or extrapolated data so that the decisions needed can be made, and the project work can proceed. In this view, professional ignorance is a thoughtful response to a governance situation that is far from optimal, but wherein project actors nonetheless remain capable of action plans under conditions including competing goals, shifting preferences and struggles over the authority to define problems. Seen in this view, professional ignorance is the capacity to "meet the policy makers halfway," i.e. to recognize the difficulty of providing complete policy instructions given cognitive and temporal limitations, etc., while at the same time making also vague or incomplete policy decisions actionable in the domain where they are implemented.

To formulate a more general theoretical contribution to the professional ignorance literature (e.g. Jeon, 2020; Schaefer, 2019; Souleles, 2019; McGoey, 2012), it is first noteworthy that the semantic meaning of the term ignorance is loaded with negative associations. Still, ignorance can be helpful as it protects the individual or the project team from ending up in a stalemate wherein the lack of detailed information would otherwise prevent further action. In this view, professional ignorance is tangential to what Daston (2019) refers to as intuition, being a key term in cognition science studies but also in the management studies literature (see, e.g. Dane and Pratt, 2007; Khatri and Ng, 2000; Simon, 1987), denoting the capacity to apprehend social reality as a "distinctive form of understanding" that grasps the whole and "reveals interconnections," but on basis of cognitive fragments of the totality of the social reality (Daston, 2019, p. 331). "Ideally," Daston (2019, p. 331) continues, intuition "seizes upon essentials" and "forges a whole out of disparate parts or steps." In the intuitive understanding of social reality, the sum is always of necessity larger than the parts, but also inconclusive data and incomplete information can be used to generate an image of social reality that is sufficiently coherent to be supportive of individual or joint action. The deliberate inattention (professional ignorance) or intuition-based comprehension of professional scholars is consequently less of a vice than it is a mode of understanding, a quality of an epistemic community that is trained to act on basis of data and information that is oftentimes far from complete but that demands that action are to be taken just the same. Future scholarly research on the role of professional ignorance "in the wild" and "on the ground" is therefore 
welcome, not the least in management studies, wherein many policies and decisions are dependent on professional groups' joint capacity to ignore the incompleteness of available data or information. Also in the domain of urban studies research, the concept of professional ignorance may inform scholarly research that increases the understanding of how complex urban development projects are organized.

\section{Conclusion}

Professional ignorance is a collective skill to take action even in the absence of a full and comprehensive understanding of the situation (Jeon, 2020; Souleles, 2019). In everyday semantics, ignorance is culpable as it reveals an unflattering incapacity to pay attention or to demonstrate a minimal concern for a matter at hand, but in professional work, ignorance in the form of deliberate inattention is in many cases a precondition for actions to be taken in situations wherein accurate data and information is in short supply (Davies and McGoey, 2012). The study of an urban development project demonstrates that policy makers' stipulated goals are vague (as in the case of the objective to eliminate the city district from the police authority's list) or inconsistent with factual conditions (as in the case of the ambition to create mixed housing despite low net-worth households being the intended primary residents), but that condition is mediated by the project teams' capacity to make decisions and take action also on basis of also incomplete policies. The downside risk is that in lieu of more precise policy instructions and prescribed activities, urban development teams tend to reproduce off-the-shelf solutions, i.e. as in the current case, generate additional new housing, but without necessarily grappling with the broader set of socio-economic challenges that is arguably part of a more sustainable urban development policy. Professional ignorance has primarily been recognized in scientific communities (McGoey, 2012), but the current study indicates that professional ignorance also has a role to play in governance systems, in project management and in urban development projects. Future scholarly research should preferably examine how professional ignorance enables action to be taken on basis of incomplete information in a wider set of practical undertakings and in policy making.

\section{Note}

1. The literature on ignorance and, more specifically, professional ignorance was identified and selected on basis of Google Scholar literature search. The search word "Ignorance" generated hits from publications in a variety of social science and humanities disciplines, including, e.g. philosophy. Unfortunately, few of these were of interest for the current study of urban development project, but, e.g. Abbott's (2010) article on scholarly ignorance was identified in this search. When the search period was restricted to the 2016-2020 period, a similar diversity of scholarly interests and specialisms were revealed, including papers on "ignorance," "pluralistic ignorance" and similar terms in, e.g. political science, legal studies and behavioral science journals. The search word "professional ignorance" provided a similar diversity of scholarly papers, but, e.g. the articles published by Davies and McGoey (2012) and McGoey (2012) were selected in this search. In a more limited search for the 2016-2020 period, a number of more recent articles examining ignorance in an organization and management studies context were identified and selected including, e.g. the work of Schwarzkopf (2020), Schaefer (2019) and Souleles (2019). The current article does not purport to review the full scholarly literature on ignorance, but merely constructs an analytical framework that shed light on the specific urban development project. Consequently, the literature search has not been intended to be exhausted but is merely designed to serve these ends.

\section{References}

Abbott, A. (1988), The System of Professions: An Essay on the Division of Expert Labor, Chicago University Press, Chicago and London.

Abbott, A. (2010), "Varieties of ignorance”, American Sociologist, Vol. 41 No. 2, pp. 174-189. 
QROM

16,2

296

Ansell, B. (2014), "The political economy of ownership: housing markets and the welfare state", American Political Science Review, Vol. 108 No. 2, pp. 383-402.

Bakken, T. and Wiik, E.L. (2018), "Ignorance and organization studies", Organization Studies, Vol. 39, pp. 1109-1120.

Battaglini, M. and Patacchini, E. (2019), "Social networks in policy making", Annual Review of Economics, Vol. 11, pp. 473-494.

Beswick, J. and Penny, J. (2018), "Demolishing the present to sell off the future? The emergence of 'financialized municipal entrepreneurialism' in London", International Journal of Urban and Regional Research, Vol. 42 No. 4, pp. 612-632.

Chetty, R., Hendren, N. and Katz, L.F. (2016), "The effects of exposure to better neighborhoods on children: new evidence from the moving to opportunity experiment", American Economic Review, Vol. 106 No. 4, pp. 855-902.

Citron, D.K. and Pasquale, F.A. (2014), "The scored society: due process for automated predictions", Washington Law Review, Vol. 89 No. 1, pp. 1-33.

Daft, R.L. and Weick, K.E. (1984), "Toward a model of organizations as interpretation systems", Academy of Management Review, Vol. 9 No. 2, pp. 284-295.

Dane, E. and Pratt, M.G. (2007), "Exploring intuition and its role in managerial decision making", Academy of Management Review, Vol. 32 No. 1, pp. 33-54.

Daston, L. (2019), "The coup d'oeil: on a mode of understanding", Critical Inquiry, Vol. 45 No. 2, pp. 307-331.

Davies, W. and McGoey, L. (2012), "Rationalities of ignorance: on financial crisis and the ambivalence of neo-liberal epistemology", Economy and Society, Vol. 41 No. 1, pp. 64-83.

Diamond, R. and McQuade, T. (2019), "Who wants affordable housing in their backyard? An equilibrium analysis of low-income property development", Journal of Political Economy, Vol. 127 No. 3, pp. 1063-1117.

Edelman, L. (1992), "Legal ambiguity and symbolic structures: organizational meditation of civil rights law", American Journal of Sociology, Vol. 97 No. 6, pp. 1531-1576.

Edelman, L.B., Fuller, S.R. and Mara-Drita, I. (2001), "Diversity rhetoric and the managerialization of law", American Journal of Sociology, Vol. 106 No. 6, pp. 1589-1641.

Eisenhardt, K.M., Graebner, M.E. and Sonenshein, S. (2016), "Grand challenges and inductive methods: rigor without rigor mortis”, Academy of Management Journal, Vol. 59 No. 4, pp. 1113-1123.

Faber, J.W. (2020), "We built this: consequences of New Deal era intervention in America's racial geography”, American Sociological Review, Vol. 85 No. 5, pp. 739-775.

Fennell, L.A. (2017), “Searching for fair housing”, Boston University Law Review, Vol. 97, pp. 349-424.

Fields, D. and Uffer, S. (2016), "The financialisation of rental housing: a comparative analysis of New York City and Berlin", Urban Studies, Vol. 53 No. 7, pp. 1486-1502.

Fine, G.A. (1996), Kitchens: The Culture of Restaurant Work, University of California Press, Berkeley, Los Angeles and London.

Fotaki, M. (2010), "Why do public policies fail so often? Exploring health policy-making as an imaginary and symbolic construction", Organization, Vol. 17 No. 6, pp. 703-720.

Fourcade, M. and Healy, K. (2013), "Classification situations: life-chances in the neoliberal era", Accounting, Organizations and Society, Vol. 38 No. 8, pp. 559-572.

Freidson, E. (2001), Professionalism: The Third Logic, The University of Chicago Press, Chicago.

Funk, R.J. and Hirschman, D. (2014), "Derivatives and deregulation: financial innovation and the demise of glass-steagall", Administrative Science Quarterly, Vol. 59 No. 4, pp. 669-704.

Gerring, J. (2004), "What is a case study and what is it good for?", American Political Science Review, Vol. 98 No. 2, pp. 241-354. 
Gerrity, M.S., Earp, J.A.L., DeVellis, R.F. and Light, D.W. (1992), "Uncertainty and professional work: perceptions of physicians in clinical practice", American Journal of Sociology, Vol. 97 No. 4, pp. 1022-1051.

Gillham, B. (2000), Case Study Methods, Continuum, London \& New York.

Gioia, D.A., Corley, K.G. and Hamilton, A.L. (2013), "Seeking qualitative rigor in inductive research: notes on the Gioia methodology", Organizational Research Methods, Vol. 16 No. 1, pp. 15-31.

Goffman, E. (1983), "The interaction order: American sociological association, 1982 presidential address", American Sociological Review, Vol. 48 No. 1, pp. 1-17.

Guironnet, A., Attuyer, K. and Halbert, L. (2016), "Building cities on financial assets: the financialisation of property markets and its implications for city governments in the Paris city-region”, Urban Studies, Vol. 53 No. 7, pp. 1442-1464.

Hayward, M.L.A. and Boeker, W. (1998), "Power and conflict of interest in professional firms: evidence from investment banking”, Administrative Science Quarterly, Vol. 43, pp. 1-22.

Hodgson, D.E. (2004), "Project work. The legacy of bureaucratic control in the post-bureaucratic organization”, Organization, Vol. 11 No. 1, pp. 81-100.

Jeon, J. (2020), "Invisibilizing politics: accepting and legitimating ignorance in environmental sciences", Social Studies of Science, Vol. 49 No. 6, pp. 839-862.

Karger, H. (2005), Shortchanged: Life and Debt in the Fringe Economy, Berrett-Koehler Publishers, Oakland.

Kear, M. (2017), "Playing the credit score game: algorithms, 'positive' data and the personification of financial objects”, Economy and Society, Vol. 46 Nos 3-4, pp. 346-368.

Kellogg, K.C. (2014), "Brokerage professions and implementing reform in an age of experts", American Sociological Review, Vol. 79 No. 5, pp. 912-941.

Keys, B.J., Mukherjee, T., Seru, A. and Vig, V. (2009), "Did securitization lead to lax screening? Evidence from subprime loans", Quarterly Journal of Economics, Vol. 125, pp. 307-362.

Khatri, N. and Ng, H.A. (2000), "The role of intuition in strategic decision making", Human Relations, Vol. 53 No. 1, pp. 57-86.

Kiviat, B. (2019), "The moral limits of predictive practices: the case of credit-based insurance scores", American Sociological Review, Vol. 84 No. 6, pp. 1134-1158.

Kosack, S. and Fung, A. (2014), "Does transparency improve governance?”, Annual Review of Political Science, Vol. 17, pp. 65-87.

Kroll, J.A., Huey, J., Barocas, S., Felten, E.W., Reidenberg, J.R., Robinson, D.G. and Yu, H. (2017), “Accountable algorithms", University of Pennsylvania Law Review, Vol. 165 No. 3, pp. 633-705.

Lauer, J. (2017), Creditworthy: A History of Consumer Surveillance and Financial Identity in America, Columbia University Press, New York.

Lenfle, S. and Söderlund, J. (2019), "Large-scale innovative projects as temporary trading zones: toward an interlanguage theory", Organization Studies, Vol. 40 No. 11, pp. 1713-1739.

Lifshitz-Assaf, H. (2018), "Dismantling knowledge boundaries at NASA: the critical role of professional identity in open innovation", Administrative Science Quarterly, Vol. 63 No. 4, pp. 746-782.

McGoey, L. (2012), "Strategic unknowns: towards a sociology of ignorance", Economy and Society, Vol. 41, pp. 1-16.

Mehrpouya, A. and Salles-Djelic, M.L. (2019), "Seeing like the market; exploring the mutual rise of transparency and accounting in transnational economic and market governance", Accounting, Organizations and Society, Vol. 76, pp. 12-31.

Metcalf, G. (2018), "Sand castles before the tide? Affordable housing in expensive cities", Journal of Economic Perspectives, Vol. 32 No. 1, pp. 59-80.

Miller, P. (2001), "Governing by numbers: why calculative practices matter”, Social Research, Vol. 68 No. 2, pp. 379-395. 
QROM

16,2
Polillo, S. (2011), "Money, moral authority, and the politics of creditworthiness", American Sociological Review, Vol. 76 No. 3, pp. 437-464.

Poon, M. (2007), "Scorecards as devices for consumer credit: the case of fair, Isaac and company incorporated", The Sociological Review, Vol. 55 No. s2, pp. 284-306.

Pozen, D.E. (2018), “Transparency's ideological drift”, Yale Law Journal, Vol. 126 No. 1, pp. 100-165.

Riles, A. (2011), Collateral Knowledge: Legal Reasoning in the Global Financial Markets, The University of Chicago Press, Chicago.

Romano, R. (2005), "The Sarbanes-Oxley Act and the making of quack corporate governance", Yale Law Journal, Vol. 114, pp. 1521-1611.

Rona-Tas, A. and Hiss, S. (2010), "The role of ratings in the subprime mortgage cris: the art of corporate and the the science of consumer credit rating is", Research in the Sociology of Organizations, Vol. 30A, pp. 115-155.

Schaefer, S.M. (2019), "Willful managerial ignorance, symbolic work and decoupling: a sociophenomenological study of 'managing creativity", Organization Studies, Vol. 40 No. 9, pp. 1387-1407.

Schwartz, H.M. and Seabrooke, L. (2008), "Varieties of residential capitalism in the international political economy: old welfare states and the new politics of housing", Comparative European Politics, Vol. 6, pp. 237-261.

Schwarzkopf, S. (2020), "Sacred excess: organizational ignorance in an age of toxic data", Organization Studies, Vol. 41 No. 2, pp. 197-217.

Shapiro, S.P. (2005), "Agency theory”, Annual Review of Sociology, Vol. 31, pp. 263-284.

Simon, H.A. (1987), "Making management decisions: the role of intuition and emotion", Academy of Management Executive, Vol. 1 No. 1, pp. 57-64.

Souleles, D. (2019), "The distribution of ignorance on financial markets", Economy and Society, Vol. 48 No. 4, pp. 510-531.

Stake, R.E. (1996), The Art of Case Study Research, Sage, Thousand Oaks, London \& New Delhi.

Strauss, A.L. and Corbin, J. (1998), Basics of Qualitative Research, 2nd ed., Sage, Thousand Oaks, London, New Delhi.

Van Bortel, G., Gruis, V., Nieuwenhuijzen, J. and Pluijmers, B. (Eds) (2019), Affordable Housing Governance and Finance: Innovations, Partnerships and Comparative Perspectives, Routledge, Abingdon \& New York.

Weber, R. (2010), "Selling city futures: the financialization of urban redevelopment policy", Economic Geography, Vol. 86 No. 3, pp. 251-274.

Weick, K.E. (1995), Sensemaking in Organizations, Sage, London.

Westphal, J.D. and Bednar, M.K. (2005), "Pluralistic ignorance in corporate boards and firms' strategic persistence in response to low firm performance", Administrative Science Quarterly, Vol. 50 No. 2, pp. 262-298.

Westphal, J. and Zajac, E. (2001), "Decoupling policy from practice: the case of stock repurchase programs", Administrative Science Quarterly, Vol. 46 No. 2, pp. 202-228.

Whyte, W.F. ([1943]1993), Streetcorner Society, Chicago University Press, Chicago,

Yakura, E.K. (2002), "Charting time: timelines as temporal boundary objects", Academy of Management Journal, Vol. 45 No. 5, pp. 956-970.

\section{Corresponding author}

Alexander Styhre can be contacted at: alexander.styhre@handels.gu.se

For instructions on how to order reprints of this article, please visit our website:

www.emeraldgrouppublishing.com/licensing/reprints.htm

Or contact us for further details: permissions@emeraldinsight.com 